\title{
On the cultivation of free-living marine and estuarine nematodes
}

\author{
T. Moens \& M. Vincx \\ University of Gent, Biology Department, Marine Biology Section, \\ K. L. Ledeganckstraat 35, B-9000 Gent, Flanders, Belgium
}

\begin{abstract}
Although a large body of literature exists on the systematics and ecology of free-living marine and brackish-water nematodes, key questions on the nature and magnitude of interactions between nematodes and other organisms in the benthos remain unanswered. Relatively few authors have investigated live nematodes in food web studies or in experiments dealing with the nematodes' response to a varying environment. It is mainly for the latter purpose that attempts have been made to maintain, rear and cultivate selected species. This paper describes the methodology used for the maintenance, rearing, and eventual permanent agnotobiotic cultivation of a variety of estuarine nematodes. Spot plates, where small samples of sediment or macrophyte material are inoculated on a sloppy agar layer, have been used for the purpose of maintenance and initial cultivation. Those species that reproduce on spot plates are then selected for monospecific cultivation on agar layers with different nutrient enrichments and with micro-organisms cotransferred from the spot plates as food. Mixtures of bacto and nutrient agar prepared in artificial seawater were specifically suitable for the xenic cultivation of nine bacterivorous and, when supplied with Erdschreiber nutrients, two algivorous/bacterivorous nematode species. Up to three generations of five other nematode species have been reared under laboratory conditions, and several more were kept alive and active for variable periods of time on agar. Generation times observed on spot plates for Adoncholaimus fuscus and Oncholaimus oxyuris were substantially shorter than previously published estimates and suggest a correspondingly higher predatory and scavenging potency for these and related enoplids. A procedure for the long-term storage of nematodes at $-80^{\circ} \mathrm{C}$ with glycerol as a cryoprotectant was successfully used for Diplolaimella dievengatensis, Panagrolaimus sp. 1, and Pellioditis marina, but not for Diplolaimelloides meyli. The authors have also summarized the existing literature on the cultivation of marine and brackish-water nematodes. Continuous cultivation appears to have been successfui mainly for Aufwuchs and epiphytic nematodes; only few sediment-dwellers have been established in permanent culture. Of only just over 30 species that have ever been cultivated, more than half belong to one family (Monhysteridae) and three are Rhabditida, an order poorly represented in the marine environment. Four species have been grown in monoxenic and one in axenic culture, the latter though with limited success. It is concluded that our understanding of the basic nutritional requirements of marine nematodes is as yet insufficient, and that the culture techniques which have so far mainly deployed agar or liquid substrates, while being suitable for the cultivation of Aufwuchs and epiphytic nematodes, do not accurately enough mimic gradients specific of the natural habitat of many sediment-dwellers.
\end{abstract}

Key words: nematodes, marine, estuarine, Westerschelde Estuary, cultivation, agnotobiotic, xenic, axenic, maintenance.

\section{INTRODUCTION}

Free-living nematodes are the numerically dominant metazoan representatives of the benthos of many marine and brackish-water habitats, attaining densities of up to several million individuals $\mathrm{m}^{-2}$ and a corresponding biomass of 0.1 to $10 \mathrm{~g} \mathrm{C} . \mathrm{m}^{-2}$ (Heip et al., 
1985). Their rôle in the benthic food web is, however, poorly understood. Nematodes may graze a significant fraction of microalgal and/or bacterial production (Montagna, 1995); their bioturbatory activity may influence sediment diffusion coefficients for a variety of solutes, including $\mathrm{O}_{2}$ (Aller \& Aller, 1992; Alkemade et al., 1992) and enhances the surface area available for microbial degradation processes (Nehring et al., 1990; Nehring, 1991); their mucous secretions may serve as a substrate for a variety of micro-organisms (Riemann \& Schrage, 1978; Warwick, 1981a; Jensen, 1996); and the nematodes may serve as a food source for epi- and hyperbenthic predators (cf. Gerlach \& Schrage, 1969; Bell \& Coull, 1978; Gee, 1989; Coull, 1990; Service et al., 1992; Hamerlynck \& Vanreusel, 1993). The magnitude of all these interactions, however, remains largely unknown for lack of experimental evidence on the nematodes' activity and production. The study of these aspects in the animals' natural environment is severely hampered by methodological constraints.

Most marine and estuarine nematode species - except for some large and slowly reproducing members of, for example, the Enoplidae, Oncholaimidae, Halichoanolaimidae, and Desmodoridae (Gerlach \& Schrage, 1971, 1972; Malakhov, 1974; Heip et al., 1978) - develop and reach sexual maturity within days, weeks or a few months, depending on a variety of external factors such as temperature and food. Reproduction is usually continuous, and the nematodes' fertile period is often relatively long compared to the preadult phase (Woombs \& Laybourn-Parry, 1984). Consequently, generations strongly overlap in the field (Skoolmun \& Gerlach, 1971), and it is therefore extremely difficult to study species "cohorts". As a result, classical approaches towards the calculation of production are virtually impossible. Similarly, the physiological status (age, feeding condition, stress level, ...) of animals sampled from the field is largely unknown, thus imposing severe constraints on their use in standardized laboratory experiments.

Artificial culture systems of free-living marine and brackish-water nematodes can therefore provide an almost unlimited source of information: Under controlled conditions. life cycles as influenced by a changing abiotic (e.g. temperature, salinity) or biotic (e.g. food levels) environment can be studied. Moreover, actively reproducing, monospecific nematode cultures are a continuous source of live material of which age and physiological status are known within acceptable limits. It thus becomes possible to perform reproducible experiments, such as measurements of respiration or food uptake. Although data obtained from laboratory experiments cannot a priori be extrapolated to field situations, they appear in many cases to offer the most reliable basis for the study of direct interactions between nematode populations and environmental variables.

Recently, the tremendous success of the terrestrial nematode Caenorhabditis elegans as a model system for genetic, molecular and developmental studies has fuelled the interest of scientists previously unrelated to marine nematode research to study the variation of some of these aspects among the close relatives of $C$. elegans. Laboratory cultures of some brackish-water species established by the authors are currently being used for the study of embryonic development (Gaëtan Borgonie \& Bart Vancoppenolle, pers. comm.). In addition, monospecific nematode cultures can be a reliable source of material for phylogenetic studies using gene sequence data, which until recently seldom included any marine species (but see Blaxter et al., 1998; Bates et al., 1998); it is indeed often difficult to reliably identify living nematodes in a multispecies sample, and the traditional 
formaldehyde-preserved specimens are unsuitable because the formaldehyde is detrimental to DNA.

Kinne (1977) reviewed the different culture techniques used for marine nematodes. Vranken (1985) compiled most of the literature on the cultivation of marine and brackishwater nematodes up to 1985 , but his $\mathrm{PhD}$.-thesis is not generally available to the scientific public. Since then, only few novel attempts have been published. The authors of this paper have summarized the information from the literature and have added data from the results and experience they have gained during five years of experimental work with a nematode community from the Westerschelde Estuary, S.W. Netherlands.

\section{Terminology}

In the following we will refer to cultures only in the case of those artificial systems which provide all the necessary nutriments for the nematodes to sustain reproduction and a full development of the resulting progeny into reproductive adults, and this - theoretically (i.e. assuming timely transfer to new medium) - indefinitely. We somewhat arbitrarily take five as the minimum number of generations to be attained in order to use the term culture, since essential nutrients or growth-promoting factors may be needed only in trace amounts and may, when present in the initial nematode inoculum, sustain reproduction for up to two or three generations while being absent from the medium (Vanfleteren, 1980). In all other cases, we simply use the term maintenance.

Nematode cultures can be either agnotobiotic or gnotobiotic. Gnotobiotic refers to "the study of a single species in the absence of other organisms or in the presence of known species" (Koenning \& Barker, 1985). Agnotobiotic or xenic, then, implicitly includes the presence of live organisms the identity of which has not been determined. To further specify the gnotobiotic level, we adopt the terminology proposed by Dougherty $(1959,1960)$. In short, mono-, di-, tri-, and polyxenic cultures have one, two, three, and more than three associated species, respectively; axenic cultures have none. Except for the latter, all these are synxenic cultures, i.e., they have one or more known organisms associated with the target nematode species.

Culture media can be either holidic, meridic, or oligidic (Dougherty, 1959, 1960). A holidic medium is made up entirely of chemically defined constituents; a meridic medium adds at least one substance of unknown structure to a holidic basis; and an oligidic medium provides most of the dietary requirements in the form of a crude extract (e.g. liver extract).

\section{MATERIALS, METHODS AND RESULTS}

\section{Sampling, initial isolation and maintenance}

The authors are currently studying (1) the feeding behaviour of selected species of intertidal estuarine nematodes (Moens \& Vincx, 1997); (2) the effect of environmental factors such as temperature, salinity and food levels on growth and reproduction of these species; and (3) possible competitive interactions (Moens et al,, 1996b) between these nematode species as a means to elucidate some of the driving forces behind the patchiness observed in most marine and brackish-water meiobenthic communities. For this purpose, two sampling sites in the Westerschelde Estuary (SW Netherlands), one in the me- 


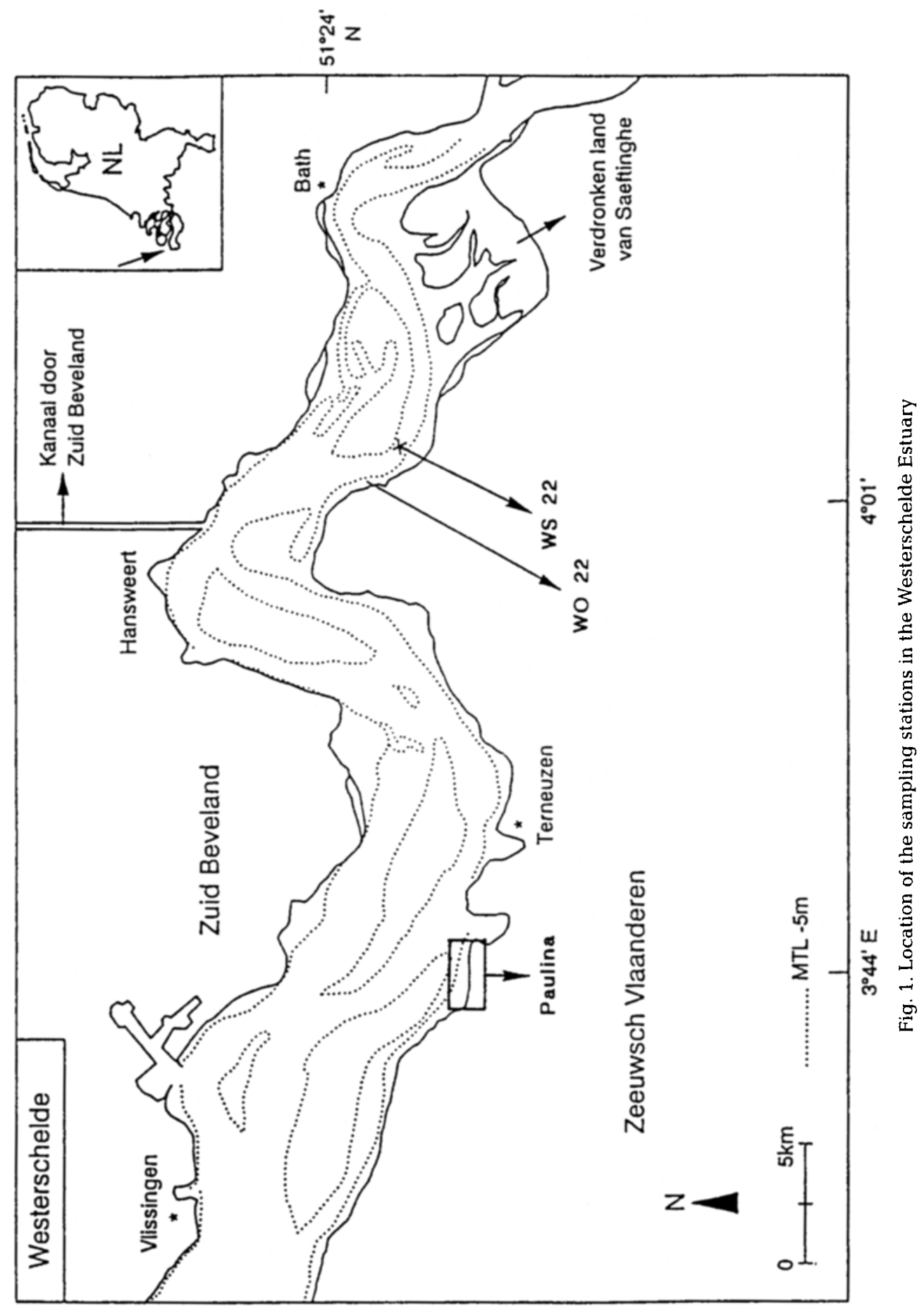


sohaline (at Walsoorden) and one in the polyhaline (the Paulina salt marsh and adjacent tidal flats) reach, were selected (Fig. 1). At Walsoorden, a transect on an intertidal sandflat from high to low tide level, with the two main stations located near the extremes of this tidal span, was sampled. The sediment composition gradually changes from a muddy, fine sand near the high tide level to a coarser sediment with a low silt fraction near the low tide level. The temporal variability of the nematode community of a station near the high tide level (WO22) and of a subtidal station (WS22) were extensively studied over a one-year cycle in 1991-1992 ( $\mathrm{Li}, 1993 ; \mathrm{Li} \& \mathrm{Vincx}, 1993$; Li et al., 1997). Some isolated patches of the cordgrass Spartina anglica were also sampled, as well as Fucus vesiculosus stands at the basis of the dike and small deposits of macrophyte detritus (mainly Spartina anglica, Fucus vesiculosus, Ulva lactuca and some Phragmites australis) if present.

At the Paulina, a fairly coarse grained station with low silt fraction on an intertidal flat, a silty station at the margin of the marsh, and about 25 arbitrarily defined microhabitats on the marsh, including stems and both green and dead leaves of Spartina anglica, of Aster tripolium and of Limonium vulgare, roots of S. anglica and of Salicornia sp., stands of Fucus vesiculosus, sediment in and at the edges of two shallow gullies and in two small and very shallow puddles, etc ... were sampled. Sampling was irregular from November 1992 onwards at Walsoorden and monthly from August 1995 to December 1997 at the Paulina.

Most samples were taken as bulk collections of either macrophyte material or of the top $1 \mathrm{~cm}$ of sediment, gathered in large Petri dishes (14 cm diameter) or plastic buckets, and transported as rapidly as possible to the laboratory. Both sampling locations are within a $1 \mathrm{~h}$ drive from the laboratory, and the collected material was either treated immediately upon our return or stored in a cold room $\left(8-10^{\circ} \mathrm{C}\right)$ until sorting took place, usually the next day.

Animals were harvested by washing one or a few "handfuls" of sediment or macrophyte material with copious amounts of $0.45 \mu \mathrm{m}$ millipore filtered habitat water in a large (5-1) beaker. This slurry was forcefully agitated and the contents subsequently allowed to settle for 1-2 min., before decanting over a 38- or a $63-\mu \mathrm{m}$ sieve. Longer settling times can strongly reduce the amount of sediment retained on the sieve, but often result in loss of especially large-sized nematodes. This procedure was repeated five to ten times, depending on the type of sediment to be washed. The fraction retained on the sieve was then collected in a small amount of filtered habitat water in 250-ml glass beakers and stored in the fridge until further processing. Nematodes survived storage in this way for days, weeks, or even a few months; the latter was especially true for large-sized nematodes such as Adoncholaimus fuscus, Enoploides longispiculosus and E. spiculohamatus. Long survival periods (up to 20 months) for nematodes stored in cold seawater have previously been noted for Deontostoma californicum (Viglierchio \& Johnson, 1971) and for Oncholaimus brachycercus and Desmodora scaldensis (Gerlach \& Schrage, 1972). At times, washing was performed with tap water instead of habitat water. This resulted in a variable mortality of nematodes and other meiofauna, but contrary to occasional marine sediment samples treated in this way, a majority of animals usually survived this treatment and regained "normal" activity a few minutes after being returned to a brackish medium. Some nematodes (e.g. Daptonema sp.), however, appeared particularly sensitive to this type of osmotic shock. 
Table 1. Composition of some media commonly used in marine nematode cultivation

\begin{tabular}{|c|c|c|c|}
\hline \multicolumn{4}{|l|}{ Erdschreiber medium } \\
\hline $\mathrm{NaNO}_{3}$ & \multicolumn{3}{|l|}{$100.0 \mathrm{mg}$} \\
\hline $\mathrm{NH}_{4} \mathrm{Cl}$ & \multicolumn{3}{|l|}{$0.5 \mathrm{mg}$} \\
\hline $\mathrm{K}_{2} \mathrm{HPO}_{4}$ & \multicolumn{3}{|l|}{$10.0 \mathrm{mg}$} \\
\hline $\mathrm{Na}_{2} \mathrm{SiO}_{3} \cdot 9 \mathrm{H}_{2} \mathrm{O}$ & \multicolumn{3}{|l|}{$10.0 \mathrm{mg}$} \\
\hline thiamine & \multicolumn{3}{|l|}{$1.0 \mu \mathrm{g}$} \\
\hline cobalamine & \multicolumn{3}{|l|}{$1.0 \mu \mathrm{g}$} \\
\hline soil extract & \multicolumn{3}{|c|}{$10.0 \mathrm{ml}$} \\
\hline \multicolumn{4}{|c|}{ autoclaved habitat water or artificial seawater to $1000 \mathrm{ml}$} \\
\hline \multicolumn{4}{|l|}{ Killian medium } \\
\hline solution a & \multicolumn{3}{|c|}{ solution $b$} \\
\hline $\mathrm{NaNO}_{3}$ & $2 \mathrm{~g}$ & $\mathrm{NaH}_{2} \mathrm{PO}_{4}$ & $4 \mathrm{~g}$ \\
\hline $\mathrm{KNO}_{3}$ & $2 \mathrm{~g}$ & $\mathrm{CaCl}_{2}$ & $4 \mathrm{~g}$ \\
\hline $\mathrm{NH}_{4} \mathrm{NO}_{3}$ & $1 \mathrm{~g}$ & $\mathrm{FeCl}_{3}$ & $2 \mathrm{~g}$ \\
\hline \multirow[t]{2}{*}{ aqua dest. to } & \multirow[t]{2}{*}{$1000 \mathrm{ml}$} & conc. $\mathrm{HCl}$ & $2 \mathrm{ml}$ \\
\hline & & aqua dest. to & $800 \mathrm{ml}$ \\
\hline \multicolumn{4}{|c|}{$\begin{array}{l}2 \mathrm{ml} \text { of solution a and } 1 \mathrm{ml} \text { of solution b and } 20 \mathrm{ml} \text { of soil extract are combined with ASW or } \\
\text { habitat water to form } 1000 \mathrm{ml}\end{array}$} \\
\hline \multicolumn{4}{|l|}{ Artificial seawater } \\
\hline solution a & & solution b & \\
\hline $\mathrm{NaCl}$ & $239.0 \mathrm{~g}$ & $\mathrm{Na}_{2} \mathrm{SO}_{4} \cdot 10 \mathrm{H}_{2} \mathrm{O}$ & $90.6 \mathrm{~g}$ \\
\hline $\mathrm{MgCl}_{2} \cdot 6 \mathrm{H}_{2} \mathrm{O}$ & $108.3 \mathrm{~g}$ & $\mathrm{NaHCO}_{3}$ & $0.2 \mathrm{~g}$ \\
\hline $\mathrm{CaCl}_{2}$ anhydrous & $11.5 \mathrm{~g}$ & $\mathrm{NaF}$ & $0.003 \mathrm{~g}$ \\
\hline $\mathrm{SrCl}_{2} \cdot 6 \mathrm{H}_{2} \mathrm{O}$ & $0.04 \mathrm{~g}$ & $\mathrm{H}_{3} \mathrm{BO}_{3}$ & $0.027 \mathrm{~g}$ \\
\hline $\mathrm{KCl}$ & $6.82 \mathrm{~g}$ & aqua dest. to & $1000 \mathrm{ml}$ \\
\hline $\mathrm{KBr}$ & $0.99 \mathrm{~g}$ & & \\
\hline aqua dest. to & $8560 \mathrm{ml}$ & & \\
\hline
\end{tabular}

\section{Some important media and nutritional supplements}

In the following, reference will be made to several nutrient media and some nutritional supplements regularly used in our nematode cultures. Table 1 lists the composition of the modified Killian medium (von Thun, 1966), of the modified Erdschreiber medium (Hällfors, in Jensen, 1982), and of the artificial seawater (Dietrich \& Kalle, 1957).

The soil extract is prepared by boiling an amount of sediment or soil in water. The extract is decanted and allowed to settle for a while. In the meantime, its $\mathrm{pH}$, which is usually slightly acidic, is adjusted to neutral with $\mathrm{NaHCO}_{3}$ or $\mathrm{NaOH}$. After settling, the extract is again decanted and repeatedly filtered, first over paper filters and subsequently over 0.8 and $0.45 \mu \mathrm{m}$ membrane filters, until a transparent yellow liquid is obtained (Lee et al., 1970). This extract can then be stored frozen for prolonged periods.

The artificial seawater (ASW) of Dietrich \& Kalle (1957) has an approximate salinity of 35 psu. Brackish salinities can easily be derived by dilution with distilled water. Because the buffering capacity of the artificial seawater is inferior to that of habitat water, and its $\mathrm{pH}$ usually slightly lower, TRIS- $\mathrm{HCl}$ buffer of $\mathrm{pH} 7.5$ to 8.0 was routinely added in a final concentration of $5 \mathrm{mM}$.

In general, nematodes appear incapable of synthesizing sterols from a purely bac- 
terial food source (Hieb \& Rothstein, 1968; Bolla, 1979; Vanfleteren, 1980). Hence, in media without crude extracts and with bacteria as the sole food, a sterol supplement was routinely added. Vranken et al. (1984) used a mixture of five different sterols, each at $10 \mu \mathrm{g} \cdot \mathrm{ml}^{-1}$ after Hieb \& Rothstein (1968) and Vanfleteren (1980), but this can be replaced without ill consequence by cholesterol at $50 \mu \mathrm{g} \cdot \mathrm{ml}^{-1}$ (J. Vanfleteren, pers. comm.).

We regularly supplemented cultures of several species with $E$. coli lysate as a food source. This consists of an extremely dense suspension of $E$. coli $\left(5.10^{11}\right.$ cells.ml $\left.{ }^{-1}\right)$ stored frozen and subsequently thawed. Upon thawing, a majority of cells burst, yielding a rich nutritional source to either nematodes or their associated bacteria. Some $E$. coli survive the freezing-and-thawing and also grow on the remains of the dead cells.

\section{The use of spot plates}

Small samples of untreated sediment, macrophyte material or detritus, or of meiofauna retained on sieves after washing of bulk samples (see above), were inoculated on top of thin sloppy agar layers or in excavations made in these agar layers in Petri dishes $(9 \mathrm{~cm}$ in diam.). We have coined the term spot plates for these inoculations. Bacto-agar (DIFCO) was dissolved in modified Killian nutrient medium prepared with $0.45 \mu \mathrm{m}$ millipore filtered habitat water; however, especially when the fauna associated with decaying macrophyte material ("Aufwuchs" fauna) was targeted, agar layers prepared with habitat water but without nutrient additions yielded similar results. A 0.7 to $0.8 \%$ agar (percentages are expressed as weight percentages) was commonly used, since most nematodes encountered in our samples easily penetrated this agar concentration, while increasing concentrations prohibited penetration and movement of progressively more species. Still lower agar concentrations $(0.2$ to $0.5 \%)$ further facilitated movement of nematode species sensitive in this respect, but usually could not be kept longer than two or three weeks, a period during which they turned almost completely fluid as a result of the microbial growth in the agar. Typically, 12 to $15 \mathrm{ml}$ of agar were poured in a Petri dish $(9 \mathrm{~cm}$ in diam.). Thicker layers of agar were unsuitable, because nematodes penetrating deeper down tended to become trapped and died.

After one or a few days, a variable fauna and microflora emerged from the inoculated material and colonized the surrounding agar. Blooms of the most abundant species present in the inoculum were almost invariably reflected in the spot plates as well, but were often overgrown within days or a few weeks by one or a few opportunistic species; this held for diatoms, ciliates, nematodes, and harpacticoid copepods, and probably for other fauna and microflora, too.

A variety of species thrived well on spot plates, i.e. they remained active and fed for up to two or three months. Egg deposition (or deposition of juveniles in the case of ovoviviparous nematodes), egg hatch, and (partial) maturation have been noted for, i.a., 18 species listed in Vranken (1985) and for Daptonema setosum, Metadesmolaimus sp., Theristus acer*, Praeacanthonchus punctatus, Metachromadora remanei, Calyptronema maxweberi, Spilophorella sp., Dichromadora cephalata *, D. geophila, Ptycholaimellus ponticus, Chromadora macrolaima, Hypodontolaimus balticus, Leptolaimus papilliger, Sphaerolaimus gracilis, Anoplostoma viviparum *, Oncholaimus oxyuris ", and Adoncholaimus fuscus, and for the species now in continuous culture (see Table 2) (the present study). Ten out of the 18 species listed by Vranken also developed in our spot plates (those 
marked with ", and Geomonhystera disjuncta, Monhystera parva, Diplolaimella dievengatensis, Monhystrella parelegantula, Pellioditis marina, and Chromadora nudicapitata). Yet more species behaved actively but did not reproduce in spot plates.

\section{Setting up an agnotobiotic culture}

The spot plate setup was used for observations of feeding behaviour and preferences (Moens \& Vincx, 1997) as a basis for selecting food types for more specific culture attempts. Some radiotracer feeding experiments (modified after Lee et al., 1966, 1970; Tietjen et al., 1970) were performed, but often yielded conflicting results. In general, single food organisms selected in this way proved inadequate to sustain reproduction of any nematode species (see also Ban et al., 1997, for similar results with copepods). Nematode species to be further cultivated were selected on the basis of their activity in the spot plates. If available, small spots dominated by one nematode species or with clear in situ reproduction were transferred to selected media (see below). Micro-organisms cotransferred served as the putative food. Cotransferred nematodes belonging to other than the target species were removed under the stereomicroscope. If fewer than, for example, 25 nematodes of the same species were present in the inoculum, more individuals were hand-picked from the spot plates, rinsed twice in $0.22 \mu \mathrm{m}$ millipore filtered habitat water, and added.

Initially, only species which were observed to feed predominantly on bacterial aggregates or on unicellular algae were selected. For the latter, 0.6 to $0.8 \%$ bacto-agar layers were prepared with modified Killian medium or with Erdschreiber medium, because these two media supported the best growth of a variety of microalgae (see also Lee et al., $1970)$.

Initial attempts at cultivating mainly bacteria-feeding nematode species with single amino acid (glycin) or carbohydrate (glucose) additions or with Vlasblommedium (Vranken et al., 1984) added to bacto-agar layers failed to sustain continuous reproduction of any of the nematodes tested. The three named additions often caused excessive bacterial growth, resulting in a high nematode mortality. On the other hand, bacto-agar layers enriched only with Killian nutrient medium and sterols supported too limited a bacterial growth to sustain a high level of reproduction of most of the species tested. Only for Leptolaimus papilliger and for Monhystrella parelegantula did this medium yield generation times similar and - only for L. papilliger - densities comparable to those observed in nutrient agar enriched (see further) media. Continuous reproduction of Diplolaimella dievengatensis, Geomonhystera disjuncta, Pellioditis marina, Panagrolaimus sp. 1, and Diplolaimelloides meyli was obtained on agar layers prepared with Vlasblommedium but with a lower glycin concentration and with the addition of cholesterol. However, for the former three species, the densities obtained were far lower than those previously reported under almost identical culture conditions (Vranken, 1985; Vranken et al., 1984).

Eventually, the best results were obtained with agar layers prepared of mixtures of bacto and nutrient agar (both from DIFCO) in weight/weight ratios of $10 / 1$ to $3 / 1$. These supported a high but not excessive bacterial growth, and appeared perfectly suited for the cultivation of Aufwuchs species, especially those belonging to the families Rhabditidae, Panagrolaimidae, and Monhysteridae. Initially, these mixed bacto-nutrient agar 
Tabie 2. List of nematodes currently in continuous agnotobiotic culture in the present authors' laboratory, with details on origin, culture medium and associated organisms. $\mp$ All populations originate from the Westerschelde Estuary, except this particular $P$. marina population which was isolated from the west coast of Zanzibar, eastern Africa. (") The composition of these media is given in Table 1

\begin{tabular}{|c|c|c|c|c|c|c|}
\hline Species & Source & Habitat & Substrate & $\begin{array}{l}\text { conc. } \\
(\%)\end{array}$ & $\begin{array}{l}\text { Nutrient } \\
\text { additions }\end{array}$ & $\begin{array}{l}\text { Associate } \\
\text { organisms }\end{array}$ \\
\hline $\begin{array}{l}\text { Diplolaimelloides } \\
\text { meyli }\end{array}$ & Walsoorden & $\begin{array}{l}\text { dead Spartina } \\
\text { leaves }\end{array}$ & $\mathrm{B} / \mathrm{N} 4 / 1$ & 1 & none & bacteria \\
\hline $\begin{array}{l}\text { Diplolaimella } \\
\text { dievengatensis }\end{array}$ & Walsoorden & $\begin{array}{l}\text { dead Spartina } \\
\text { leaves }\end{array}$ & $\mathrm{B} / \mathrm{N} 4 / 1$ & 1 & none & bacteria \\
\hline Monhystera sp. & Paulina & $\begin{array}{l}\text { Salicornia } \\
\text { roots }\end{array}$ & $\mathrm{B} / \mathrm{N}$ 4/1 & 1 & none & bacteria \\
\hline $\begin{array}{l}\text { Geomonhystera } \\
\text { disjuncta }\end{array}$ & Walsoorden & $\begin{array}{l}\text { Fucus } \\
\text { serratus }\end{array}$ & $\mathrm{B} / \mathrm{N} 4 / 1$ & 0.8 & none & bacteria \\
\hline $\begin{array}{l}\text { Monhystera } \\
\text { parva }\end{array}$ & Paulina & Enteromorpha & $\mathrm{B} / \mathrm{N} 10 / 1$ & 0.6 & $\begin{array}{l}\text { Erdschrei- } \\
\text { ber }\left({ }^{\circ}\right)\end{array}$ & see text \\
\hline $\begin{array}{l}\text { Monhystrella } \\
\text { parelegantula }\end{array}$ & Paulina & Enteromorpha & $\mathrm{B} / \mathrm{N} 10 / 1$ & 0.8 & $\begin{array}{l}\text { Erdschrei- } \\
\text { ber }\left(^{\circ}\right)\end{array}$ & bacteria \\
\hline $\begin{array}{l}\text { Pellioditis } \\
\text { marina }\end{array}$ & Walsoorden & $\begin{array}{l}\text { Fucus } \\
\text { serratus }\end{array}$ & $\mathrm{B} / \mathrm{N} 4 / 1$ & 1 & none & bacteria \\
\hline $\begin{array}{l}\text { Pellioditis } \\
\text { marina }\end{array}$ & Zanzibar $¥$ & $\begin{array}{l}\text { sandy } \\
\text { sediment }\end{array}$ & $\mathrm{B} / \mathrm{N} 4 / 1$ & 1 & none & bacteria \\
\hline $\begin{array}{l}\text { Pellioditis } \\
\text { marina }\end{array}$ & Paulina & $\begin{array}{l}\text { Spartina } \\
\text { roots }\end{array}$ & $\mathrm{B} / \mathrm{N} 4 / 1$ & 1 & none & bacteria \\
\hline $\begin{array}{l}\text { Panagrolaimus } \\
\text { sp. } 1\end{array}$ & Walsoorden & $\begin{array}{l}\text { dead Spartina } \\
\text { leaves }\end{array}$ & $\mathrm{B} / \mathrm{N} 4 / 1$ & 1 & none & bacteria \\
\hline $\begin{array}{l}\text { Panagrolaimus } \\
\text { sp. } 1\end{array}$ & Paulina & $\begin{array}{l}\text { Fucus } \\
\text { serratus }\end{array}$ & $\mathrm{B} / \mathrm{N} 4 / 1$ & 1 & none & bacteria \\
\hline $\begin{array}{l}\text { Panagrolaimus } \\
\text { sp. } 2\end{array}$ & Paulina & $\begin{array}{l}\text { dead Spartina } \\
\text { leaves }\end{array}$ & $\mathrm{B} / \mathrm{N} 4 / 1$ & 1 & none & bacteria \\
\hline $\begin{array}{l}\text { Chromadora } \\
\text { nudicapitata }\end{array}$ & Paulina & $\begin{array}{l}\text { dead Spartina } \\
\text { leaves }\end{array}$ & $\mathrm{B} / \mathrm{N} 10 / 1$ & 0.8 & $\begin{array}{l}\text { Erdschrei- } \\
\text { ber }\left({ }^{\circ}\right)\end{array}$ & see text \\
\hline $\begin{array}{l}\text { Leptolaimus } \\
\text { papilliger }\end{array}$ & Paulina & sediment & $\mathrm{B} / \mathrm{N} 10 / 1$ & 0.8 & $\begin{array}{l}\text { Killian } \\
\text { medium (") }\end{array}$ & $\begin{array}{l}\text { bacteria, } \\
\text { ciliates, } \\
\text { flagellates }\end{array}$ \\
\hline
\end{tabular}

layers were prepared in modified Killian medium, but so far we have been able to omit this extra nutrient enrichment without ill consequences for eight out of 11 species tested (see Table 2). Two of the three remaining nematodes feed on a mixed diet of bacteria and microalgae (see below), and the third was lost from culture after only two generations on bacto-nutrient agar layers due to a fungus infection. Sterols are present as impurities in the nutrient agar portion and consequently do not have to be added separately. We also replaced the habitat water by artificial seawater of salinities corresponding to the aver- 
age salinities in the sampling stations. This further improved our culture results (see Table 3), mostly because it strongly reduced the often high variability between subsequent subculturing events. The Westerschelde is a very eutrophic estuary, and differences in the organic load of the water may have been responsible for the observed variability, by triggering different bacteria present in the stocks to dominate the agar layers. Poor nematode growth indeed often appeared related to bacteria, rare in the stock cultures, overgrowing the subcultures.

Attempts were made to cultivate the following predominantly diatom-feeding species: Daptonema setosum, Theristus acer, Monhystera parva, Dichromadora sp., Chromadora nudicapitata, Hypodontolaimus balticus and Ptycholaimellus ponticus, on agar layers with a variety of unidentified diatoms, unicellular chlorophytes and bacteria as food. Of these, only $C$. nudicapitata and $M$. parva were established in fairly dense, continuous cultures on agar, initially prepared with Killian medium; the soil extract portion has been omitted without ill effects (Table 3). Organisms associated with cultures of the former nematode are a euglenoid flagellate, a unicellular chlorophyte (both as yet unidentified), the diatom Cylindrotheca closterium (though at very low densities) and

Table 3. List of nematodes currently in continuous agnotobiotic culture in the present authors' laboratory, with details on the number of subsequent generations obtained and on minimum generation times under the abiotic conditions specified.

\begin{tabular}{|c|c|c|c|c|c|c|}
\hline Species & $\mathrm{T}\left({ }^{\circ} \mathrm{C}\right)$ & Salinity & $\begin{array}{c}\text { Culture } \\
\text { period } \\
\text { (months) }\end{array}$ & $\begin{array}{l}\text { Approximate } \\
\text { number } \\
\text { of generations }\end{array}$ & $\begin{array}{l}\text { Appr. min } \\
\text { gen. time } \\
\text { (days) }\end{array}$ & $\begin{array}{c}\text { Max. } \\
\text { density } \\
\text { (per ml) }\end{array}$ \\
\hline $\begin{array}{l}\text { Diplolaimelloides } \\
\text { meyli }\end{array}$ & 20 & 15 & 60 & 150 & 11 & $>1000$ \\
\hline $\begin{array}{l}\text { Diplolaimella } \\
\text { dievengatensis }\end{array}$ & 20 & 25 & 54 & 125 & 10 & $>1000$ \\
\hline $\begin{array}{l}\text { Geomonhystera } \\
\text { disjuncta }\end{array}$ & 18 & 25 & 36 & 75 & 9 & $>1000$ \\
\hline Monhystera sp. & 20 & 25 & 41 & 90 & 12 & $>1000$ \\
\hline Monhystera parva & 18 & 25 & 5 & 8 & 14 & $100>x>10$ \\
\hline $\begin{array}{l}\text { Monhystrella } \\
\text { parelegantula }\end{array}$ & 25 & 25 & 6 & 10 & 13 & $>100$ \\
\hline Pellioditis marina & 20 & 15 & 50 & 250 & 4 & $>400$ \\
\hline Pellioditis marina & 25 & 30 & 26 & 130 & 4 & $>600$ \\
\hline Pellioditis marina & 20 & 25 & 5 & 20 & 4 & $>600$ \\
\hline Panagrolaimus sp. 1 & 20 & 15 & 57 & 240 & n.d. & $>1000$ \\
\hline Panagrolaimus sp. 1 & 20 & 25 & 6 & 20 & n.d. & $>1000$ \\
\hline Panagrolaimus sp. 2 & 20 & 25 & 30 & 60 & n.d. & $>100$ \\
\hline $\begin{array}{l}\text { Chromadora } \\
\text { nudicapitata }\end{array}$ & 18 & 25 & 34 & 60 & 15 & 100 \\
\hline $\begin{array}{l}\text { Leptolaimus } \\
\text { papilliger }\end{array}$ & 20 & 25 & 11 & 20 & n.d. & $50>x>10$ \\
\hline
\end{tabular}


unidentified bacteria; with the latter they are $C$. closterium, a unicellular chlorophyte and unidentified bacteria. Observations showed that feeding activity in these cultures (determined from observations of oesophageal contractions) was aimed more at bacteria or dissolved substances than at the associated microalgae. Attempts to eliminate the microalgae by dark incubations, however, invariably failed: nematodes became inactive and died from the second generation onwards. On the other hand, addition of $E$. coli lysate at a density of $10^{9}$ cells. $\mathrm{ml}^{-1}$ to starved cultures of both species immediately triggered growth and new reproduction. However, here too, cultures reared on the bacterial lysate as the sole diet (but with a sterol addition) died out from the second generation onwards. These observations are suggestive of a mixed bacteria/microalgae diet for C. nudicapitata and $M$. parva, with the microalgae probably providing an essential nutritional factor. Vranken (1985) already successfully cultivated both species on a diet of microalgae (five species of diatoms and the chlorophyte Dunaliella salina) and unidentified bacteria.

Three consecutive generations of Dichromadora sp. were reared, but fitness (determined from size, activity, food uptake, and reproduction) of the progeny decreased from generation to generation, and third generation adults were unable to reproduce. Also, diatom associations inoculated together with the nematodes tended to become overgrown by one or two opportunistic species (esp. Cylindrotheca closterium and an unidentified chlorophyte) which appeared less suitable for sustaining growth of Dichromadora sp.. Cultivating the micro-organisms separately in liquid cultures and spreading them on agar layers a few days before these are inoculated with nematodes (Lee et al., 1970; Vranken, 1985) may largely overcome these difficulties. One generation of $H$. balticus and of $P$. ponticus was reared, but here too, the resulting adults were not reproductively active. Daptonema setosum and $T$. acer deposited eggs which all hatched, but the juveniles matured only to the second and third or fourth stage, respectively.

One predominantly ciliate-feeding nematode, Tripyloides gracilis (Moens \& Vincx, 1997), was isolated and maintained xenically in bacto-nutrient agar layers prepared with Killian medium, together with unidentified bacteria and three ciliate species. Tripyloides gracilis was a regular but slow colonizer of spot plates, and readily deposited eggs in the agnotobiotic plates. Egg hatch was virtually $100 \%$, and all juveniles were active for at least several days. Maturation, however, was completed in only seven out of 42 observed juveniles, and only one of these appeared reproductive (female; copulation with a male from the initial inoculum, and deposition of four eggs). In most other juveniles, development stopped or retarded at the J3 stage.

Attempts to cultivate predatory nematodes focused on Oncholaimus oxyuris, Adoncholaimus fuscus (both facultative predators, Moens \& Vincx, 1997), Enoploides longispiculosus, E. spiculohamatus, and Sphaerolaimus gracilis. Adults of all five species were introduced in xenic cultures of Diplolaimelloides meyli with unidentified bacteria. All five were active and fed on $D$. meyli for periods of a few days to several months. Only in $S$. gracilis was mortality following inoculation high (up to $40 \%$ ). Small incisures in the agar surface in front of each inoculated $S$. gracilis facilitated their penetration of the substrate, importantly contributing to initial survival rates. Of 43 eggs deposited in one Petri dish, 29 hatched. Seven juveniles matured to J4 or adults within 35 days, but the progeny were significantly smaller than normal adults and did not reproduce.

Neither Enoploides species deposited eggs during our experiments or in spot plates, 
although egg-carrying females were always present and often remained active for up to three months. A remarkable reproductive success was obtained in one experiment with A. fuscus. One adult female and one male were transferred to a spot plate inoculated with small parts of dead Spartina anglica leaves. The predominant meiofauna associated with the leaves were $D$. meyli and some unidentified foraminiferans; the latter showed a high mortality rate from the start of the incubation. Other associated organisms present were two diatom species, at least one ciliate species, some flagellates, and several unidentified bacteria. Shortly after the start of the experiment, the female A. fuscus deposited eggs in small groups. Since most of the egg masses were deposited near or on the Spartina leaves, they could not be accurately counted. However, juveniles emerged from seven days onwards, and no less than 25 juveniles out of 29 observed matured to $\mathrm{J} 4$ or adults within 49-55 days (i.e. from egg-deposition to adult/J4). During this period, they were observed to feed in several ways, including active predation on $D$. meyli, scavenging on dead foraminiferans, and ingestion of either microparticles or dissolved substances (Moens et al., unpubl.). Upon subsequent transfer of the resulting J4/adults to bacto-agar layers enriched with Killian medium and inoculated with autoclaved dead Spartina leaves, with unidentified bacteria from the habitat and with $D$. meyli, no reproduction was obtained.

Twenty $O$. oyuris were inoculated in cultures of $D$. meyli on bacto-nutrient agar. The inoculated worms were washed only once in $0.45 \mu \mathrm{m}$ millipore filtered habitat water. One ciliate and one or two euglenoid flagellate species, as well as some unidentified bacteria, were accidentally cointroduced. Since from a previous study (Heip et al., 1978), we anticipated long generation times and consequently a need for a regular manual transfer of individuals to new medium (which often causes increased mortality), an experimental setup was designed with concentric partitions. For this purpose, we simply removed the bottom of a 5- and a $9-\mathrm{cm} \varnothing$ plastic Petri dish, and brought the remaining "rings" in the center of a $14-\mathrm{cm} \varnothing$ Petri dish. Agar was poured into the dish so that it reached exactly the same level within the three borders. The initial inoculation was within the inner $5-\mathrm{cm}$ ring, and as soon as this central zone began to turn liquid, the partition was removed with sterile forceps. The nematodes then gradually started colonizing the surrounding agar zone. The 0 . oxyuris were manually placed into the new medium; a large part of the "old" culture was removed to temper the growth of the associated organisms, and was replaced with new medium. The same procedure was repeated with the second, $9-\mathrm{cm} \varnothing$ ring. In this setup, we were able to raise three consecutive generations of $O$. oxyuris. Third generation adults (the inoculum is not included as a generation) were then transferred to a second, similar concentric plate setup, but did not further reproduce.

\section{Long-term storage of estuarine nematode cultures}

Once culture conditions for a nematode species have been optimized, sustaining stocks becomes largely a routine matter, time-consuming though it may be. Species with short generation times and a high reproductive capacity, such as $P$. marina, D. meyli, $D$. dievengatensis, G. disjuncta, Monhystera sp., and Panagrolaimus sp. 1 have to be timely transferred to new medium. This was routinely done by aseptically transferring small pieces of a densely populated culture to a new bacto-nutrient agar layer, preferentially every two weeks for $P$. marina and approximately every four weeks for the other 
mainly bacterivorous species in our cultures. Chromadora nudicapitata and M. parva may be subcultured every two months. Occasional introductions of fungi or airborne bacteria may be detrimental to a culture, and an unduly delayed renewal of the culture medium may at times cause an otherwise rare associated organism to colonize the agar with ill consequence for the target nematodes.

Furthermore, in studying the abiotic preferences of some of the species we have continuously cultivated for several years, we have been confronted with adaptation to the specific culture conditions. A P. marina population isolated on Zanzibar in July 1995 and permanently cultivated from the following October onwards, initially had the shortest generation time at $28-32^{\circ} \mathrm{C}$ (Moens, unpubl.), but by August 1997 had that same generation time at $23-27$ and at $18-25^{\circ} \mathrm{C}$ for cultures kept at 25 and $18^{\circ} \mathrm{C}$, respectively, throughout that period (Moens \& Vincx, in prep.; Vancoppenolle et al., in press).

A preliminary experiment on the storage of four nematode species at $-80^{\circ} \mathrm{C}$ was performed following protocol outlined for C. elegans (Lewis \& Fleming, 1995). Briefly, $300 \mu \mathrm{l}$ aliquots of $D$. meyli, $D$. dievengatensis, P. marina, and Panagrolaimus sp. 1 in ASW harvested from the surface of densely populated cultures containing all life stages, were $\mathrm{vol} / \mathrm{vol}$ diluted with a solution of $30 \%$ glycerol in aq. dest. and stored frozen to $-80^{\circ} \mathrm{C}$. Single replicates were taken from the freezer after one day, one week, and one month, rapidly thawed and transferred to the surface of a bacto-nutrient agar layer. After acclimation to the preferred culture temperature, regular observations were made of recovery and ability to reproduce in individuals so treated. The best survival was noted in $D$. dievengatensis, followed by Panagrolaimus sp. 1. In the former species, a majority of juveniles and some adults survived and gave rise to new cultures. Only J1 and J2 larvae of Panagrolaimus sp. 1 survived, and matured to normally reproductive adults. All adults and a majority of juveniles of $P$. marina died, but juveniles present in the female uterus the population studied was ovoviviparous - readily emerged from the dead adults and developed to normally reproductive individuals. Less than $2 \%$ of the $D$. meyli larvae survived the treatment, but were subsequently unable to give rise to new cultures. However, few $\mathrm{J} 1$ and $\mathrm{J} 2$ were present in the inoculum, and D. meyli appeared particularly sensitive to the remnants of the glycerol. The remaining glycerol may be directly toxic to the nematodes, and may also cause an excessive growth of associated bacteria when spread on bacto-nutrient agar layers. It is therefore advisable not to directly pipet the thawed sample onto an agar layer, but to first filter and rinse it to remove most of the glycerol. In general, it can be concluded that adult nematodes poorly survive the treatment, but that mainly first and second stage juveniles are variably tolerant and remain viable. No significant differences were observed between the different storage times.

\section{DISCUSSION}

\section{Agnotobiotic maintenance and cultivation}

A large body of literature exists on the systematics and ecology of free-living marine and brackish-water nematodes. Nevertheless, key questions as to the nature and magnitude of interactions between nematodes and other organisms in the benthic food web remain unanswered. Methodological constraints to the work with live nematodes have cau- 
sed a general focus on descriptive studies dealing with preserved sediment samples. Comparatively few authors have investigated live nematodes in tracer-aided food web studies or in laboratory experiments dealing with the response of these nematodes to a varying environment. It is mainly for the latter purpose that attempts have been made to maintain, rear and cultivate selected species.

Perhaps the first mention of an estuarine nematode's "culture" was by Chitwood \& Timm (1954), who kept Pellioditis marina (formerly Rhabditis marina) on nutrient agar layers prepared with filtered habitat water or even with tap water, in which the species temporarily survived. Long-term culture under controlled conditions was for the first time achieved, not surprisingly, with two members of the Monhysteridae, Geomonhystera disjuncta (formerly Monhystera disjuncta) and Diplolaimelloides schneideri, established in culture on a simple bacto-agar prepared with habitat water and to which oatmeal or cornmeal was added (Chitwood \& Murphy, 1964),

Table 4. A resumé of marine and brackish-water nematodes which have been cultivated for at least five consecutive generations, with details on the substrate, culture media, and minimum generation times. Tgen. $=$ minimum generation time; mean (minimal) reported values between identical stages of two subsequent generations are given, but slight differences may occur depending on the stage used for reference. n.d. = not determined, n.s. = not specified in the original paper. " no regular observations were made, but in one experiment evidence was given for a completion of a generation in less than 23 days. " minimum generation time not directly determined but calculated from the net reproductive rate per generation and instantaneous rate of maximum increase. $\cdots$ small pieces

of agar in a layer of habitat or artificial water were used. with the addition of fungal mycelia

\begin{tabular}{|c|c|c|c|c|c|}
\hline Species & $\begin{array}{l}\text { Tgen. } \\
\text { mean } \\
\text { (min.) }\end{array}$ & $\begin{array}{l}\text { Sub- } \\
\text { strate }\end{array}$ & Salinity & $\begin{array}{l}\text { Tempe- } \\
\text { rature } \\
\left({ }^{\circ} \mathrm{C}\right)\end{array}$ & Reference \\
\hline 1 Diplolaimella chitwoodi & n.d. & liquid & n.s. & n.s. & Findlay (1982) \\
\hline 2 Diplolaimella dievengatensis & $10.2(?)$ & agar & 20 & 20 & $\begin{array}{l}\text { Vranken et al. } \\
\text { (1984) }\end{array}$ \\
\hline 3 Diplolaimella ocellata & $29(22)$ & agar & 15 & $20-22$ & von Thun (1968) \\
\hline 3 Diplolaimella ocellata & $6(5)$ & agar & 15 & 30 & Hopper et al. (1973) \\
\hline 4 Diplolaimella schneideri & $40(?)$ & agar & $\begin{array}{l}\text { sea } \\
\text { water }\end{array}$ & $20-24$ & $\begin{array}{l}\text { Chitwood \& } \\
\text { Murphy (1964) }\end{array}$ \\
\hline 5 Diplolaimella bruciei & $5.5(?)$ & liquid & 26 & 30 & Warwick (1981b) \\
\hline 6 Diplolaimella oschei & $29(23)$ & agar & 20 & $20-22$ & von Thun (1968) \\
\hline 7 Diplolaimella islandica & $31(24)$ & agar & 15 & $20-22$ & von Thun (1968) \\
\hline 8 Diplolaimelloides sp. & $4(4)$ & agar & 15 & 33 & Hopper et al. (1973) \\
\hline 9 Geomonhystera disjuncta & $30(?)$ & agar & $\begin{array}{l}\text { sea } \\
\text { water }\end{array}$ & $20-24$ & $\begin{array}{l}\text { Chitwood \& } \\
\text { Murphy (1964) }\end{array}$ \\
\hline 9 Geomonhystera disjuncta & $23(18)$ & agar & 5 & $20-22$ & von Thun (1968) \\
\hline 9 Geomonhystera disjuncta & $12(8)$ & $\operatorname{agar} \cdots$ & 32 & $17-22$ & $\begin{array}{l}\text { Gerlach \& } \\
\text { Schrage (1971) }\end{array}$ \\
\hline 9 Geomonhystera disjuncta & $8.6(?)$ & agar & 30 & 17 & $\begin{array}{l}\text { Vranken et al. } \\
(1984)\end{array}$ \\
\hline
\end{tabular}


Table 4 (Continued)

\begin{tabular}{|c|c|c|c|c|c|}
\hline Species & $\begin{array}{l}\text { Tgen. } \\
\text { mean } \\
\text { (min.) }\end{array}$ & $\begin{array}{l}\text { Sub- } \\
\text { strate }\end{array}$ & Salinity & $\begin{array}{l}\text { Tempe- } \\
\text { rature } \\
\left({ }^{\circ} \mathrm{C}\right)\end{array}$ & Reference \\
\hline 10 Monhystera filicaudata & $29.5(24)$ & liquid & estuarine & $20-25$ & Tietjen (1967) \\
\hline 10 Monhystera denticulata & $10(8)$ & agar & 26 & 25 & $\begin{array}{l}\text { Tietjen \& Lee } \\
(1972)\end{array}$ \\
\hline 11 Monhystera parva & $8.8(?)$ & agar & 30 & 22 & Vranken (1985) \\
\hline 11 Monhystera parva & $11.5(?)$ & agar & 20 & 20 & Vranken (1985) \\
\hline 12 Monhystrella parelegantula & $<30(23)^{*}$ & agar $\mp$ & $\begin{array}{l}\text { sea } \\
\text { water }\end{array}$ & n.s. & $\begin{array}{l}\text { Hopper \& Meyers } \\
\text { (1966) }\end{array}$ \\
\hline 12 Monhystrella parelegantula & $8.9(?)$ & agar & 30 & 25 & $\begin{array}{l}\text { Vranken et al. } \\
\text { (1981) }\end{array}$ \\
\hline 13 Theristus pertenuis & $23(19)$ & $\operatorname{agar}^{* *}$ & 32 & $17-22$ & $\begin{array}{l}\text { Gerlach \& Schrage } \\
\text { (1971) }\end{array}$ \\
\hline 14 Pellioditis marina & $4.5(4.5)$ & agar & 25 & 25 & Tietjen et al. (1970) \\
\hline 14 Pellioditis marina & $1.5(1)$ & agar & 15 & 33 & Hopper et al. (1973) \\
\hline 14 Pellioditis marina & $3.5(3)$ & n.s. & n.s. & room $\mathrm{T}^{\circ}$ & Sudhaus (1974) \\
\hline 14 Pellioditis marina & $20(14)$ & agar & 25 & 5 & $\begin{array}{l}\text { Berghoiz \& } \\
\text { Brenning (1978) }\end{array}$ \\
\hline 14 Pellioditis marina & $4.5(4)$ & agar & 20 & 25 & $\begin{array}{l}\text { Vranken \& Heip } \\
\text { (1983) }\end{array}$ \\
\hline 15 Chromadora axi & n.d. & agar & n.s. & n.s. & Lee et al. (1970) \\
\hline $\begin{array}{l}16 \text { Chromadora } \\
\text { macrolaimoides }\end{array}$ & $22(18)$ & $\begin{array}{l}\text { agar/ } \\
\text { liquid }\end{array}$ & 26 & 25 & $\begin{array}{l}\text { Tietjen \& Lee } \\
(1973)\end{array}$ \\
\hline 17 Chromadora nudicapitata & $13(?)$ & n.s. & n.s. & 20 & Warwick (1981a) \\
\hline 17 Chromadora nudicapitata & $9.7(8.5)$ & agar & 30 & 22 & Vranken (1985) \\
\hline 17 Chromadora nudicapitata & $14(12.5)$ & agar & 20 & 20 & Vranken (1985) \\
\hline 18 Chromadora quadrilinea & n.d. & agar & n.s. & n.s. & Lee et al. (1970) \\
\hline 19 Chromadora sp. & n.d. & agar & n.s. & n.s. & Lee et al. (1970) \\
\hline 20 Chromadorina germanica & $12(?) \cdots$ & liquid & 26 & 25 & $\begin{array}{l}\text { Tietjen \& Lee } \\
(1977)\end{array}$ \\
\hline 21 Chromadorita tenuis & $26(19)$ & agar & 15 & $20-22$ & von Thun (1968) \\
\hline 21 Chromadorita tenuis & $20(?)$ & agar & 6 & 18 & Jensen (1983) \\
\hline $\begin{array}{l}22 \text { Neochromadora } \\
\text { poecilosomoides }\end{array}$ & $21.7(17.5)$ & agar & 30 & 20 & Vranken 1985 \\
\hline 23 Leptolaimus papilliger & n.d. & agar & n.s. & n.s. & $\begin{array}{l}\text { Bouwman et al. } \\
\text { (1984a) }\end{array}$ \\
\hline 24 Paracanthonchus caecus & $51.1(46)$ & agar & 20 & 20 & Heip et al. (1985) \\
\hline 25 Eudiplogaster pararmatus & $21(?)$ & agar & 5 & 21 & $\begin{array}{l}\text { Romeyn et al. } \\
\text { (1983) }\end{array}$ \\
\hline
\end{tabular}


The purpose of these authors, as in many later works with laboratory-reared nematodes, was to study the influence of environment (here temperature) on the reproduction of marine nematodes. Although a review and discussion of this particular aspect is beyond the aim of the present paper, one cannot help but noticing two important features related to this topic. First, it is clear that nematodes can sometimes be cultivated for long periods (Chitwood \& Murphy, 1964; Bergholz \& Brenning, 1978; Table 4) under conditions which, not taking into account temperature or salinity, are suboptimal. The specific culture conditions greatly influence the population parameters so deduced. For example, the first estimates of the minimum generation times of Monhysteridae were about fivefold those found later under optimal conditions, although experiments were conducted under a similar temperature and salinity regime (Table 4). Secondly, while it has been generally accepted that large-sized enoplid nematodes have long generation times, i.e. in the order of several months to two years, our results on Oncholaimus oxyuris and Adoncholaimus fuscus as well as previous data on Enoplus paralittoralis and Oncholaimus sp. (Hopper et al., 1973) support the idea that, under optimal conditions, these nematodes are capable of completing an entire generation in one to two months. As such, they may react in a rather more versatile way to optimal environmental conditions than previously suspected, and since many among them are facultatively or mainly predatory species (Moens \& Vincx, 1997, and references herein), their impact on other benthic organisms may potentially be much greater.

Among the reports dealing with laboratory-kept nematodes, a significant fraction concerned the maintenance and rearing of one to three generations of a species, but not their actual cultivation. We have summarized those reports which we consider to be cultures in the above sense of the word (see terminology) in Table 4. In general, some indication of the number of generations should be available; we have, however, also included less documented cases if they concerned species which have successfully been cultivated under similar conditions elsewhere. Nematodes of which less than five consecutive generations were raised or where insufficient information is available to decide upon the distinction between maintenance and cultivation are listed in Table 5. Most nematodes have been maintained or cultivated under agnotobiotic conditions. It will be obvious even from a brief glance at Table 4 that the cultivated species constitute a fraction not representative of a typical marine or brackish-water nematode community, but strongly biased towards species of so-called Aufwuchs communities. Out of a total of only just under 30 species that have truly been cultivated, 16 belong to the family Monhysteridae, with six, three, at least three, one, and one representatives of the genera Diplolaimelloides, Diplolaimella, Monhystera, Geomonhystera, and Monhystrella, respectively; a further three are rhabditids, a group that in terms of species diversity is extremely poorly represented in the marine environment. Several of these species have been isolated from vastly different areas and cultivated by different researchers. All these species, and Theristus pertenuis (belonging to the order Monhysterida, but to the family Xyalidae), can be considered deposit feeders ingesting mainly bacteria, microalgae, and/or other similarly sized particles (Wieser, 1953; Jensen, 1987; Moens \& Vincx, 1997). The remainder are mainly epistratum feeders, which use their buccal armature to scrape off small particles - mainly microalgae - from a substrate; these particles are then pierced and their contents ingested (Wieser, 1953; Jensen, 1982, 1987; Moens \& Vincx, 1997). Nine of these species have been cultivated, among which no less than five belonging to the genus 
Chromadora, three others to the closely related genera Chromadorita, Chromadorina, and Neochromadora, and finally Eudiplogaster pararmatus. Here too, some nematodes e.g. C. nudicapitata - can be considered fairly typical Aufwuchs species.

Extremely few typically benthic species have been cultivated under controlled conditions. Leptolaimus papilliger was cultivated in agar layers for 18 months (Bouwman et al., 1984a), but no further specifications were given about the culture methods used. We cultivated the same species in rather low densities for 11 consecutive generations, but then lost the cultures due to a fungus infection. Right now, we are establishing novel cultures of Leptolaimus sp. from the Paulina. Some oncholaimid nematodes have been maintained on agar for a few successive generations, but in total, at most, one fifth of the marine and brackish-water nematodes that have been cultivated can be considered typically or predominantly sediment-dwelling species. It has been suggested that an agar medium limits the motility of such sediment-dwellers, whereas it would fairly accurately mimic the natural substrate of many epiphytic and Aufwuchs nematodes (Bouwman, 1983). This is, however, not supported by observations on the activity of many species in spot plates (Vranken, 1985; the present study). Moreover, the nutritional requirements of aquatic nematodes are still poorly understood. Alternatively, the specific chemical gradients in the upper sediment layers are virtually impossible to mimic in agar, and may be important determinants of many nematodes' ability to survive and reproduce. Alternative incubation techniques, like the one recently designed for the cultivation of phototrophic sulphur

Table 5. Literature overview of nematodes which have been maintained for one to four generations, but not established in continuous culture, with details on the substrate used. $f$ indicates addition of fungal mycelia. - Number of generations not specified, but species kept in continuous culture for 25 months. Since no data on this nematode's generation time are available, the present authors cannot conclude whether this species deserves to be listed in Table 4 rather than in Table 5

\begin{tabular}{|c|c|c|}
\hline Species & Substrate & Reference \\
\hline Adoncholaimus thalassophygas & agar & von Thun (1968) \\
\hline Oncholaimus brachycercus & agar & Gerlach \& Schrage (1972) \\
\hline Oncholaimus oxyuris & agar & Heip et al. (1978) \\
\hline Oncholaimus paralangruensis & agar & Lee et al. (1970) \\
\hline Oncholaimus sp. & agar & Hopper et al. (1973) \\
\hline Viscosia carnleyensis * & liquid & Lee et al. $(1970)$ \\
\hline Viscosia macramphida & $\operatorname{agar} \mp$ & Hopper \& Meyers (1970) \\
\hline Enoplus paralittoralis & agar & Hopper et al. (1973) \\
\hline Haliplectus dorsalis & agar & Hopper et al. (1973) \\
\hline Halichoanolaimus robustus & agar & Gerlach \& Schrage (1972) \\
\hline Desmodora scaldensis & liquid & Gerlach \& Schrage (1972) \\
\hline Acanthonchus cobbi & $\operatorname{agar} t$ & Hopper \& Meyers (1966) \\
\hline Monhystera sp. & $\operatorname{agar} t$ & Hopper \& Meyers (1966) \\
\hline Monhystera refringens & agar & Trotter \& Webster (1984) \\
\hline Geomonhystera disjuncta & agar & Trotter \& Webster (1984) \\
\hline Chromadora macrolaimoides & liquid $\Psi$ & Hopper \& Meyers (1966) \\
\hline Chromadorina epidemos & liquid $\mathrm{f}$ & Hopper \& Meyers (1966) \\
\hline Euchromadora gaulica & liquid $\Phi$ & Hopper \& Meyers (1966) \\
\hline Prochromadora orleyi & liquid & Bergholz \& Brenning (1978) \\
\hline Prochromadorella neapolitana & agar & Trotter \& Webster (1984) \\
\hline
\end{tabular}


bacteria (Pringault et al., 1996), may fairly accurately mimic some of these gradients and as such offer an interesting potential for the cultivation of more species.

\section{Choosing a substrate}

Sloppy agar layers have so far proved to be the most successful substrate for the cultivation of brackish-water and marine nematodes. From the first attempts onwards (Chitwood \& Timm, 1954; Chitwood \& Murphy, 1964; von Thun, 1966, 1968) agar proved useful both for the maintenance and - provided nutritional additions were made - cultivation of several species. The importance of the physical characteristics of the agar layers has been noted as early as 1970 , and relates to such aspects as slope of the agar surface (Lee et al., 1970; Tietjen et al., 1970), concentration of the agar used (e.g. Vranken, 1985; the present study), and depth of the agar layer (Lee et al., 1970; the present stuy). It would appear that marine and brackish-water nematodes do not thrive well on agar concentrations above $1 \%$, contrary to many terrestrial and parasitic nematodes which are routinely kept on a 2 to $3 \%$ agar. The need for the nematodes to be able to burrow in the agar was nicely demonstrated by the high mortality of Sphaerolaimus gracilis remaining on the agar surface, while individuals in the agar moved swiftly and remained active for several weeks. In this study, we have aimed at a compromise between some nematodes' preference for a very sloppy agar $(0.2-0.6 \%)$ that rapidly turns liquid, and the need to store the cultures for prolonged periods. We have therefore chosen a $1 \%$ agar where possible; species sensitive in this respect, especially Monhystera parva, are kept on a $0.6-0.8 \%$ agar.

Alternatively, nematodes have been maintained in liquid media, usually based on filtered habitat water to which a food source was added. Desmodora scaldensis was unable to survive on sloppy agar layers, but remained active for long periods in seawater with small pieces of the macrophyte Laminaria (Gerlach \& Schrage, 1972). Bergholz \& Brenning (1978) studied the generation times of Prochromadora orleji in habitat water with the addition of a soil extract and detritus of Enteromorpha intestinalis. Deontostoma californicum remained active for several months in habitat water and in a variety of salt solutions, provided bicarbonate and phosphate concentrations in the medium were low (Viglierchio \& Johnson, 1971). Tietjen \& Lee (1977) kept Chromadorina germanica in liquid Erdschreiber medium with the addition of two microalgae as a food source. Attempts to cultivate marine nematodes in a liquid medium have, however, been fewer than in agar. Tietjen (1967) reared Monhystera filicaudata in habitat water with pieces of decaying Zostera marina, but the generation times so obtained were suspiciously long compared to other members of the Monhysteridae. With microalgae as a food source, Chromadora macrolaimoides and Chromadorina germanica were raised in ASW enriched with soil extract and in liquid Erdschreiber medium, respectively (Tietjen \& Lee, 1973, 1977). Alongi \& Tietjen (1980) studied interactions between G. disjuncta, Diplolaimella sp. and C. germanica in liquid Erdschreiber medium when diatoms were the food and in autoclaved seawater with mixed cereal when bacteria were the food. They observed that $C$. germanica specifically adhered to the cereal flakes, while both Monhysteridae were more evenly distributed throughout the medium. A special growth column, where nematodes could be siphoned off without disturbance to the rest of the culture, was designed for the cultivation of Diplolaimelloides bruciei (Warwick, 1981b). The 
growth medium for this species was autoclaved habitat water with $0.1 \%$ cereal. We were able to establish continuous cultures of $D$. meyli in shallow ASW layers in large 2-I Erlenmeyers on a rotary shaker. Cholesterol was added at $50 \mu \mathrm{g} \cdot \mathrm{ml}^{-1}$, and $E$. coli lysate at a final density of approximately $10^{9}$ cells. $\mathrm{ml}^{-1}$ served as the food source. Whether $D$. meyli fed on the $E$. coli lysate or on the bacteria cotransferred with the nematodes is unclear. Less than $500 \mathrm{ml}$ of such liquid cultures yielded approximately $1 \mathrm{~g}$ of nematodes (wet weight). A few generations of $D$. dievengatensis and Monhystera sp. were reared under identical conditions, but especially for the latter species, activity in the liquid environment was low, adults grew larger and became sluggish, females deposited fewer eggs, and the entire population proved extremely sensitive to even minor changes in the concentration of the $E$. coli lysate offered as food. Also, our liquid cultures were only successful at relatively low temperatures $\left(18^{\circ} \mathrm{C}\right)$. The nematodes appeared to be particularly sensitive to oxygen depletion upon sudden bacterial blooms, and could not be maintained in nutrient enriched liquid media such as Killian medium or soil extract amended ASW. In general, however, nematode mortality in liquid media is high (see, for example, Tietjen et al., 1970, for observations on P. marina), and some nematodes apparently need at least small pieces of a solid substrate for the deposition of their eggs in otherwise liquid media (Vranken et al., 1981).

A completely different approach to the cultivation of marine nematodes was the fungal mat method used by a research group in Florida during the sixties. Initially developed for the study of the euryhaline stylet-bearing nematode Aphelenchoides marina (Meyers et al., 1963, 1964), this method was later used for trapping nematodes in the field and for rearing selected species (Hopper \& Meyers, 1966; Meyers \& Hopper, 1966, 1967). Marine fungi were grown in seawater enriched with yeast extract and glucose, and subsequently transferred to Erlenmeyers containing only seawater. The fungi (Dendryphiella arenaria and Halosphaeria mediosetigera were particularly suited) formed a mat which proved a suitable substrate for a variety of nematodes. In the field, they attracted large numbers of gravid females of Metoncholaimus scissus, and several more species deposited eggs which hatched upon subsequent transfer of the mats to the laboratory (Hopper \& Meyers, 1966). The same authors went on to study the population increase of Acanthonchus cobbi on $0.5 \%$ agar layers inoculated with small pieces of fungal mycelium and with Kluveromyces aestuarii, a marine yeast, as food. Similarly, the population increase of Chromadora macrolaimoides, Chromadorina epidemos, and Euchromadora gaulica, and the life cycle of Viscosia macramphida were studied in seawater with fungal mats as the substrate. We believe that the successful use of fungal mats in rearing several epistrate-feeding nematodes is not only due to the provision of a suitable substrate for egg-deposition, but also for feeding. Active foraging of several epistratum-feeders on micro-organisms or macromolecules along threads of filamentous algae has repeatedly been observed (Moens \& Vincx, 1997). These nematodes preferentially scrape off particles from a substrate or pierce unicellular or filamentous organisms, and may forage in both ways on the fungal hyphae.

\section{Synxenic and axenic cultivation}

Agnotobiotic culture procedures have repeatedly proved their use for the study of nematode life cycles as influenced by a variety of environmental conditions. Consistently 
high growth rates and correspondingly high densities, low preadult mortalities [less than $5 \%$ in our experiments with $D$. meyli, Monhystera sp. and $P$. marina $a_{i}$ less than $10 \%$ for $G$. disjuncta and $D$. dievengatensis (Vranken et al., 1984)], and short generation times are indicative of the suitability of the present agnotobiotic culture conditions and disagree with previous statements on the impredictability of reproductive rates in crude cultures (Lee \& Muller, 1975). Any effects so observed can, however, be either direct effects of the environment on the nematodes, or indirect effects via the associated food organisms. For example, if nematodes are inoculated and grown xenically with unidentified bacteria at different temperatures, the slower growth of the food organism at lower temperatures will undoubtedly influence the nematode life cycle. In order to minimize such indirect effects, we have routinely isolated bacteria from nematode stock cultures, cultivated them separately in nutrient rich liquid media (e.g. nutrient broth), spread them on the surface of agar layers and allowed them to grow for one or two days at a fixed temperature before the inoculation of nematodes. As such, food is available in excess at the start of the experiment. For some purposes, however, particularly for toxicological tests, more controlled conditions than in agnotobiotic culture on oligidic media may be needed.

A trixenic culture of Pellioditis marina with the bacteria Pseudomonas sp., Flavobacterium marinum and Micrococcus sp. was maintained for over 120 generations on marine nutrient agar and on Lee et al.'s (1970) media 9 and 10 (Tietjen et al., 1970). Tracerfeeding experiments indicated that the latter species was consumed only to a limited extent, and so the authors eliminated one or more of the bacteria with various combinations of antibiotics to arrive at monoxenic cultures on Pseudomonas sp. or on F. marinum. Only Pseudomonas sp. proved a suitable single food source, and a monoxenic culture with this bacteria was established and maintained for more than 80 generations. It is noteworthy that the media 9 and 10 did not contain sterols, although they may have been present as impurities in the soil extract portion of medium 9.

Findlay (1982) and Findlay \& Tenore (1982) mention the monoxenic cultivation of Diplolaimella chitwoodi on Gerber's mixed cereal, but give no further specifications on the culture conditions. The only other report on the establishment of monoxenic cultures of marine nematodes is by Vranken et al. $(1984,1985)$. These authors tested seven bacterial strains as potential single food sources for the nematodes G. disjuncta and Diplolaimella dievengatensis (note that the original papers mention Monhystera disjuncta and - mistakingly - Monhystera microphthalma), and were eventually able to grow monoxenic cultures of both species on the bacterial strain Alteromonas haloplanktis ISC2. For G. disjuncta, food had to be regularly added in order to obtain normal maturation, and a significant increase in egg mortality was observed after a limited number of consecutive generations in monoxenic culture (Vranken et al., 1985). The same authors also mention the monoxenic cultivation of $P$. marina on A. haloplanktis ISC2, but without further details. They also developed a chemically defined medium with which they prepared their sloppy agar layers. This medium consisted of ASW, enriched with $1 \%$ silicium, $1 \%$ amino acids and $1 \%$ Provasoli-Walne nutrient medium after Ukeles (1976) (Vranken et al., 1984).

Only one marine nematode species, $P$. marina, has ever been reared axenically, on a marine salt solution basis to which, among other components, whole sheep blood and casamino acids were added (Tietjen \& Lee, 1975). In contrast to existing axenic cultures of soil nematodes, the medium had to be further supplemented with fatty acids to obtain reproduction, which may hint at a reduced ability for fatty acid synthesis in this nematode 
(Vanfleteren, 1978). The limited reproduction obtained in axenic cultures of $P$. marina is yet more proof of our poor understanding of the nutritional requirements of marine nematodes.

A major difficulty in going from xenic to synxenic cultures is the removal of associated organisms. Microalgae have routinely been eliminated by repeated subculture in dark conditions. Ciliates and flagellates may be removed with adequate efficiency by repeated transfer of individual nematodes through sterile ASW $;$ addition of up to $0.1 \%$ of hypochlorite to this ASW may further increase that efficiency (J. Vanfleteren, pers. comm.), but while not negatively affecting $P$. marina and Panagrolaimus sp. 1 in incubations up to $30 \mathrm{~min}$., this treatment is poorly tolerated by $D$. meyli. Contaminating fungal mycelia have been removed by serial transfer through media containing fungizone, mycostatin (Tietjen et al., 1970), or nystatin (this study) in concentrations up to $50 \mathrm{mg}^{\mathrm{ml}}{ }^{-1}$. Long-term effects of these fungicides on the nematodes are unknown, but short-term incubations (up to a few days) appeared to have no ill effects. The same holds for several combinations of antibiotics which have been used for the removal of associated bacteria. Repeated rinsing in 10000 units benzylpenicillin and $10 \mathrm{mg} \cdot \mathrm{ml}^{-1}$ streptomycin sulphate, either in ASW (Moens et al., 1996a) or in sloppy agar (Vranken et al., 1984; here lower concentrations of antibiotics were used) have been used with some success, but other products with more specific antibiotic spectra may be needed to target some contaminating bacteria. The fact that a fraction of the bacteria that pass through nematode guts remain viable, in combination with delayed defaecation in starved animals (see, for example, Deutsch, 1978), may further complicate axenization procedures. Alternative axenization procedures that have been used in work with plant-parasitic and soil nematodes (cf. Koenning \& Barker, 1985; Ko et al., 1996) have hitherto not been tested on marine nematodes.

Acknowledgements. The first author has benefitted from a grant as aspirant with the Fund for Scientific Research Flanders (FWO) during a large part of the research period underlying this paper. The Flemish Ministry of Education financially supported this research by means of G.O.A. contract 92/98 08 from the University of Gent. Prof. Dr. Jacques Vanfleteren is acknowledged for many stimulating discussions and useful suggestions. Dominick Verschelde managed to transport live nematode samples from Zanzibar. Myriam Beghyn provided much valued help during the early attempts at getting that first species cultivated; Annemie Devreese and Karine De Batselier aided with the freezing experiments, and Christine Van der heyden's helpful hands have saved the authors many a late-night subculturing hour.

\section{LITERATURE CITED}

Alkemade, R., Wielemaker, A., De Jong, S. A. \& Sandee, A. J. J., 1992. Experimental evidence for the role of bioturbation by the marine nematode Diplolaimella dievengatensis in stimulating the mineralization of Spartina anglica leaves. - Mar. Ecol. Prog. Ser. 90, 149-155.

Aller, R. C. \& Aller, J. Y., 1992. Meiofauna and solute transport in marine muds. - Limnol. Oceanogr. 37, 1018-1033.

Alongi, D. M. \& Tietjen, J. H., 1980. Population growth and trophic interactions among free-living marine nematodes. In: Marine benthic dynamics. Ed. by K. R. Tenore \& B. C. Coull. Univ. of South Carolina Press, Columbia, 151-166.

Ban, S. H., Burns, C., Castel, J., Chaudron, Y., Christou, E., Escribano, R., Umani, S. F., Gasparini, S., Ruiz, F. G., Hoffmeyer, M., Ianora, A., Kang, H. K., Laabir, M., Lacoste, A., Miralto, A., Ning, X. R., Poulet, S., Rodriguez, V., Runge, J., Shi, J. X., Starr, M., Uye, S. \& Wang, Y. J., 1997. The paradox of diatom-copepod interactions. - Mar. Ecol. Prog. Ser. 157, 287-293. 
Bates, J. W., Hope, W. D. \& Litvaitis, M. K., 1998. A revised phylogeny of the Adenophorea. - Am. Zool. 37, 52A.

Bell, S. S. \& Coull, B. C., 1978. Field evidence that shrimp predation regulates meiofauna. - Oecologia 35, 141-148

Bergholz, E. \& Brenning, U., 1978. Studies on the reproductive cycles of marine nematodes (Rhabditis marina and Prochromadora orleji). - Wiss. Z. Univ. Rostock 27, 393-398.

Blaxter, M. L., De Ley, P., Garey, J. R., Liu, L. X., Scheldeman, P., Vierstraete, A., Vanfleteren, J. R., Mackey, L. Y., Dorris, M., Frisse, L. M., Vida, J. T. \& Thomas, W. K., 1998. A molecular evolutionary framework for the phylum Nematoda - Nature, Lond. 392, 71-75.

Bolla, R., 1979. Developmental nutrition of nematodes: the biochemical role of sterols, heme compounds and lysosomal enzymes. - J. Nematol. 11, 250-259.

Bouwman, L. A., 1983. Systematics, ecology and feeding biology of estuarine nematodes. - Publs. Vers. Biologisch Onderzoek Eems-Dollard Estuarium (BOEDE) 3, 1-173.

Bouwman, L. A., Romeyn, K. \& Admiraal, W., 1984a. On the ecology of meiofauna in an organically polluted estuarine mudflat. - Estuar. coast. Shelf Sci. 19, 633-653.

Bouwman, L. A., Romeyn, K., Kremer, D. R. \& van Es, F. B., 1984 b. Occurrence and feeding biology of some nematode species in estuarine aufwuchs communities. - Cah. Biol. mar. 25, 287-303.

Chitwood, B. G. \& Murphy, D. G, 1964. Observations on two marine monhysterids - their classification, cultivation and behavior. - Trans. Am. microsc. Soc. 83, 311-329.

Chitwood, B. G. \& Timm, R. W., 1954. Free-living nematodes of the Gulf of Mexico. In: Gulf of Mexico, its origin, waters, and marine life. - Fish. Bull. U.S. 89, 313-323.

Coull, B. C., 1990. Are members of the meiofauna food for higher trophic levels? - Trans. Am. microsc. Soc. 109, 233-246.

Deutsch, A., 1978. Gut structure and digestive physiology of two marine nematodes, Chromadorina germanica (Bütschli, 1874) and Diplolaimella sp. - Biol. Bull. mar. biol. Lab., Woods Hole 155 , 317-335.

Dietrich, G. \& Kalle, K. 1957. Allgemeine Meereskunde. Borntraeger, Berlin, 492 pp.

Dougherty, E. C., 1959. Introduction to axenic culture of invertebrate metazoa: A goal. - Ann. N.Y. Acad. Sci. 27, 27-54.

Dougherty, E. C., 1960. Cultivation of aschelminths, especially rhabditid nematodes. In: Nematology - fundamentals and recent advances with emphasis on plant-parasitic and soil forms. Ed. by J. N. Sasser \& W. R. Jenkins. Univ. of North Carolina Press, Chapel Hill, N.C., 297-317.

Findlay, S., 1982. Effect of detrital nutritional quality on population dynamics of a marine nematode (Diplolaimella chitwoodi). - Mar. Biol. 68, 223-227.

Findlay, S. \& Tenore, K. R., 1982. Effect of a free-living marine nematode (Diplolaimella chitwoodi) on detrital carbon mineralization. - Mar. Ecol. Prog. Ser. 8, 161-166.

Gee, J. M., 1989. An ecological and economic review of meiofauna as food for fish. - Zool. J. Linn. Soc. $96,243-261$.

Gerlach, S. A. \& Schrage, M., 1969. Freilebende Nematoden als Nahrung der Sandgarnele Crangon crangon. Experimentelle Untersuchungen über die Bedeutung der Meiofauna als Nahrung für das marine Makrobenthos. - Oecologia 2, 362-375.

Gerlach, S. A. \& Schrage, M., 1971. Life cycles in marine meiobenthos. Experiments at various temperatures with Monhystera disjuncta and Theristus pertenuis (Nematoda). - Mar. Biol. 9, 274-280.

Gerlach, S. A. \& Schrage, M., 1972. Life cycles at low temperatures in some freeliving marine nematodes. - Veröff. Inst. Meeresforsch. Bremerh. 14, 5-11.

Hamerlynck, O. \& Vanreusel, A., 1993. Mesacanthion diplechma (Nematoda: Thoracostomopsidae). a link to higher trophic levels? - J. mar. biol. Ass. U.K. 73, 453-456.

Heip, C., Smol, N. \& Absillis, V., 1978. Influence of temperature on the reproductive potential of Oncholaimus oxyuris (Nematoda, Oncholaimidae). - Mar. Biol. 45, 255-260.

Heip, C., Vincx, M. \& Vranken, G., 1985. The ecology of marine nematodes. - Oceanogr. mar. Biol. $23,399-489$.

Hieb, W. F. \& Rothstein, M., 1968. Sterol requirement of a free-living nematode. - Science, N.Y. 160. $778-779$

Hopper, B. E., Fell, J. W. \& Cefalu, R.C., 1973. Effect of temperature on life cycles of nematodes associated with the mangrove (Rhizophora mangle) detrital system. - Mar. Biol. 23, 293-296. 
Hopper, B. E. \& Meyers, S. P., 1966. Aspects of the life cycle of marine nematodes, - Helgoländer wiss. Meeresunters. 13, 444-449.

Jensen, P., 1982. Diatom-feeding behaviour of the free-living marine nematode Chromadorita tenuis. - Nematologica 28, 71-76.

Jensen, P., 1983. Life history of the free-living marine nematode Chromadorita tenuis (Nematoda: Chromadorida). - Nematologica 29, 335-345.

Jensen, P., 1987. Feeding ecology of free-living aquatic nematodes. - Mar. Ecol. Prog. Ser. 35, $187-196$.

Jensen, P., 1996. Burrows of marine nematodes as centres for microbial growth. - Nematologica 42, 320-329.

Kinne, O., 1977. Cultivation of animals: research cultivation, (7) Nematoda. In: Marine ecology. Ed. by O. Kinne. Wiley, Chichester, 3 (2), 691-709.

Ko, M. P., Schmitt, D. P. \& Sipes, B. P., 1996. Axenizing and culturing endomigratory plant-parasitic nematodes using pluronic F127, including its effects on population dynamics of Pratylenchus penetrans. - J. Nematol. 28, 115-123.

Koenning, S. R. \& Barker, K. R., 1985. Gnotobiotic techniques for plant-parasitic nematodes. In: An advanced treatise on Meloidogyne. Ed. by K. R. Barker, C. C. Carter \& J. N. Sasser. North Carolina State Univ. Graphics, North Carolina, 2, 49-66.

Lee, J. J., McEnery, M., Pierce, S., Freudenthal, H. H. \& Muller, W. A., 1966. Tracer experiments in feeding littoral foraminifera. - J. Protozool. 13, 659-670.

Lee, J. J \& Muller, W. A., 1975. Culture of salt marsh microorganisms and micrometazoa. In: Culture of marine invertebrate animals. Ed. by W. L. Smith \& M. H. Chanley. Plenum Press, New York, $87-109$.

Lee, J. J., Tietjen, J. H., Stone, R. J., Muller, W. A., Rullman, J. \& McEnery, M., 1970. The cultivation and physiological ecology of members of salt marsh epiphytic communities. - Helgoländer wiss. Meeresunters. 20,136-156.

Lewis, J. A. \& Fleming, J. T., 1995. Basic culture methods. - Meth. Cell Biol. 48, 3-29.

$\mathrm{Li}, \mathrm{J} ., 1993$. The temporal variability of free-living nematodes in a brackish tidal flat of the Westerschelde with emphasis on the use of an ecological model. PhD. Thesis, State Univ. of Gent, $81+210 \mathrm{pp}$.

Li, J. \& Vincx, M., 1993. The temporal variation of intertidal nematodes in the Westerschelde. I. The importance of an estuarine gradient. - Neth. J. aquat. Ecol, 27, 319-326.

Li, J., Vincx, M., Herman. P. M. J., 1997. Carbon flows through meiobenthic nematodes in the Westerschelde Estuary. - Fundam. appl. Nematol., 20, 487-494.

Malakhov, V. V., 1974. Life-cycle of the free-living nematode Pontonema vulgare in the White Sea. - Vest. mosk. Univ. (Ser. 4) 1, 10-14.

Meyers, S. P., Feder, W. A. \& Tsue, K. M., 1963. Nutritional relationships among certain filamentous fungi and a marine nematode. - Science, N.Y. 141, 520-522.

Meyers, S. P., Feder, W. A. \& Tsue, K. M., 1964. Studies of relationships among nematodes and filamentous fungi in the marine environment. - Devs. ind. Microbiol. 5, 354-364.

Meyers, S. P. \& Hopper, B. E., 1966. Attraction of the marine nematode, Metoncholaimus sp., to fungal substrates. - Bull. mar. Sci. 16, 142-150.

Meyers, S. P. \& Hopper, B. E., 1967. Studies on marine fungal-nematode associations and plant degradation. - Helgoländer wiss. Meeresunters. 15, 270-281.

Moens, T., Vierstraete, A., Vanhove, S., Verbeke, M. \& Vincx, M., 1996a. A handy method for measuring meiobenthic respiration. - J. exp. mar. Biol. Ecol. 197, 177-190.

Moens, T., Vierstraete, A. \& Vincx, M., 1996b. Life strategies in two bacterivorous marine nematodes: Preliminary results. - Mar. Ecol. 17, 509-518.

Moens, T. \& Vincx, M., 1997. Observations on the feeding ecology of estuarine nematodes. - J. mar. biol. Ass. U.K. 77, 211-227.

Montagna, P. A., 1995. Rates of metazoan meiofaunal microbivory: a review. - Vie Milieu 45, $1-9$.

Nehring, S., 1991. Der Röhrenbau: Eine neuentdeckte, erfolgreiche Lebensweise bei den Nematoden. - Mikrokosmos 80, 134-138.

Nehring, S., Jensen, P. \& Lorenzen, S., 1990. Tube-dwelling nematodes: tube construction and possible ecological effects on sediment-water interfaces. - Mar. Ecol. Prog. Ser. 64, 123-128. 
Pringault, O., De Wit, R. \& Caumette, P., 1996. A benthic gradient chamber for culturing phototrophic sulfur bacteria on reconstituted sediments. - FEMS Microbiol. Ecol. 20, 237-250.

Riemann, F. \& Schrage, M., 1978. The mucus-trap hypothesis on feeding of aquatic nematodes and implications for biodegradation and sediment texture. - Oecologia 34, 75-88.

Romeyn, K., Bouwman, L. A. \& Admiraal, W., 1983. Ecology and cultivation of the herbivorous brackish-water nematode Eudiplogaster paramatus. - Mar. Ecol. Prog. Ser. 12, 145-153.

Service, S. K., Feller, R. J., Coull, B. C. \& Woods, R., 1992. Predation effect of three fish species and a shrimp on macrobenthos and meiobenthos in microcosms. - Estuar. coast. Shelf Sci. 34 . $277-293$.

Skoolmun, P. \& Gerlach, S. A., 1971. Jahreszeitliche Fluktuationen der Nematodenfauna im Gezeitenbereich des Weser-Ästuars (Deutsche Bucht). - Veröff. Inst. Meeresforsch. Bremerh. 13, $119-138$.

Sudhaus, W., 1974. Nematoden (insbesondere Rhabditiden) des Strandanwurfs und ihre Beziehungen zu Krebsen. - Faun.-ökol. Mitt. 4, 365-400.

Tietjen, J. J., 1967. Observations on the ecology of the marine nematode Monhystera filicaudata Allgén, 1929. - Trans. Am. microsc. Soc. 86, 304-306.

Tietjen, J. H. \& Lee, J. J., 1972. Life cycles of marine nematodes. Influence of temperature and salinity on the development of Monhystera denticulata Timm. - Oecologia 10, 167-176.

Tietjen, J. H. \& Lee, J. J., 1973. Life-history and feeding habits of the marine nematode Chromadora macrolaimoides Steiner. - Oecologia 12, 303-314.

Tietjen, J. H. \& Lee, J. J., 1975. Axenic culture and uptake of dissolved organic substances by the marine nematode Rhabditis marina Bastian. - Cah. Biol. mar. 16, 685-693.

Tietjen, J. H. \& Lee, J. J., 1977. Life history of marine nematodes. Influence of temperature and salinity on the reproductive potential of Chromadorina germanica Bütschli. - Mikrofauna Meeresboden $15,263-270$.

Tietjen, J. H., Lee, J. J., Rullman, J., Greengart, A. \& Trompeter, J., 1970. Gnotobiotic culture and physiological ecology of the marine nematode Rhabditis marina Bastian. - Limnol. Oceanogr, 15, 535-543.

Trotter, D. B. \& Webster, J. M., 1984. Feeding preferences and seasonality of free-living marine, nematodes inhabiting the kelp Macrocystis integrifolia, - Mar. Ecol. Prog. Ser. 14, 151-157.

Ukeles, R., 1976. Cultivation of plants. Unicellular plants. In: Marine ecology. Ed. by O. Kinne. Wiley, London, $3(1), 367-466$.

Vancoppenolle, B., Borgonie, G. \& Coomans, A., 1998. Generation times of some freeliving nematodes cultured at three temperatures. - Fundam. appl. Nematol. (In press)

Vanfleteren, J. R., 1978. Axenic culture of free-living, plant parasitic and insect parasitic nematodes. - A. Rev. Phytopath. 16, 131-157.

Vanfleteren, J. R., 1980. Nematodes as nutritional models. In: Nematodes as biological models. Ed. by B.M. Zuckerman. Acad. Press, New York, 2, 47-80.

Viglierchio, D. R. \& Johnson, R. N., 1971. On the maintenance of Deontostoma californicum. - J. Nematol. 3, 86-88.

von Thun, W., 1966. Eine Methode zur Kultivierung der Mikrofauna. - Veröff. Inst. Meeresforsch. Bremerh. 2, 277-280.

von Thun, W., 1968. Autökologische Untersuchungen an freilebenden Nematoden des Brackwassers. Diss. Christian-Albrechts-Univ., Kiel, 72 pp..

Vranken, G., 1985. Een autoecologische studie van brakwatemematoden. Ph.D.-thesis, State Univ. of Gent, $282+202$ pp.

Vranken, G. \& Heip, C., 1983. Calculation of the intrinsic rate of natural increase, $\mathrm{r}_{\mathrm{m}}$, with Rhabditis marina Bastian 1865 (Nematoda). - Nematologica 29, 468-477.

Vranken, G., Thielemans, L., Heip, C. \& Vandycke, M., 1981. Aspects of the life-cycle of Monhystera parelegantula (Nematoda, Monhysteridae). - Mar. Ecol. Prog. Ser. 6, 67-72.

Vranken, G., Van Brussel, D., Vanderhaeghen, R. \& Heip, C., 1984. Research on the development of a standardized ecotoxicological test on marine nematodes. I. Culturing conditions and criteria for two Monhysterids, Monhystera disjuncta and Monhystera microphthalma. In: Ecotoxicological testing for the marine environment. Ed. by G. Persoone, E. Jaspers \& C. Claus. State Univ. of Gent and Inst. mar. scient. Res., Bredene, 2, 159-184. 
Vranken, G., Vanderhaeghen, R. \& Heip, C., 1985. Toxicity of cadmium to free-living marine and brackish-water nematodes (Monhystera microphthalma, Monhystera disjuncta, Pellioditis marina). - Dis. aquat. Org. 1,49-58.

Warwick, R. M., 1981a. Survival strategies of meiofauna. In: Feeding and survival strategies of estuarine organisms. Ed. by N. V. Jones \& W. J. Wolff. Plenum Press, New York, 39-52.

Warwick, R. M., 1981b. The influence of temperature and salinity on energy partitioning in the marine nematode Diplolaimelloides bruciei. - Oecologia 51, 318-325.

Wieser, W., 1953. Die Beziehung zwischen Mundhöhlengestalt, Ernährungsweise und Vorkommen bei freilebenden marinen Nematoden. - Ark. Zool. 4, 439-484.

Woombs, M. \& J. Laybourn-Parry, 1984. Growth, reproduction and longevity in nematodes from sewage treatment plants. - Oecologia $64,168-172$. 